\title{
The effects of wilting, molasses and inoculants on the fermentation quality and nutritive value of lucerne silage
}

\author{
F. Hashemzadeh-Cigari ${ }^{1}$, M. Khorvash ${ }^{1 \#}$, G.R. Ghorbani ${ }^{1}$ \& A. Taghizadeh $^{2}$ \\ ${ }^{1}$ Department of Animal Sciences, College of Agriculture, Isfahan University of Technology, Isfahan, \\ 84156-83111, Iran \\ ${ }^{2}$ Department of Animal Sciences, University of Tabriz, Tabriz, Iran
}

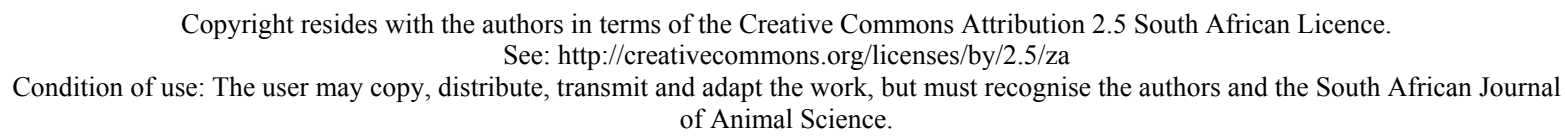

\begin{abstract}
The objective was to determine the effects of wilting, molasses and inoculants on the biochemistry and in vitro and in situ digestion of lucerne silage. Lucerne containing $200 \mathrm{~g} / \mathrm{kg}$ of dry matter (DM) was ensiled as fresh or wilted (370 g/ $\mathrm{kg} \mathrm{DM})$. Molasses, at application rates of 0,50 and $100 \mathrm{~g}$ molasses $/ \mathrm{kg} \mathrm{DM}$, was added to the chopped lucerne. Within each molasses treatment, the lucerne was applied with distilled water or with the inoculants, Ecosyl or Lalsil. Wilting lucerne increased the silage DM and water soluble carbohydrates and decreased neutral detergent fibre, acid detergent fibre, ammonia and the acetate content of the silage. Adding 50 and $100 \mathrm{~g}$ molasses $/ \mathrm{kg}$ to wilted lucerne and $100 \mathrm{~g}$ molasses $/ \mathrm{kg}$ to fresh lucerne lowered the silage $\mathrm{pH}$. Adding molasses to wilted lucerne increased the acetate content of the silage. In wilted but not in fresh lucerne both inoculants decreased the concentration of unavailable $\mathrm{N}$ in the silage. In wilted lucerne, Lalsil, but not Ecosyl, reduced the silage acetate level and in fresh lucerne both inoculants reduced the acetate level. Lalsil was more effective in wilted silages in improving the fermentation quality than Ecosyl. Both inoculants enhanced the 24-h rumen degradation of silage DM, with Lalsil being effective in wilted lucerne and Ecosyl in fresh lucerne. Molasses, at $100 \mathrm{~g} / \mathrm{kg}$, improved the in vitro silage organic matter digestion at $6,8,36$ and $48 \mathrm{~h}$ post-incubation. It was concluded that inoculating lucerne crops with Lalsil improved the fermentation quality as well as nutritive value and lowered proteolysis. These effects were more pronounced in silage with a high DM content.
\end{abstract}

Keywords: Alfalfa silage, chemical composition, Ecosyl, Lalsil, additive, wilting, gas production

\# Corresponding author: khorvash@cc.iut.ac.ir

\section{Introduction}

Optimal rumen health and profitable production of the modern ruminant industry dictate improving fibre digestion. Lucerne in the form of hay rather than silage, makes up roughly half of the dietary forage in almost all commercial dairies in Iran (Kowsar et al., 2008; Soltani et al., 2009). Feeding lucerne as silage compared to hay can reduce the selection of the cows against fibrous fractions, and thus, can prevent prolonged occurrence of sub-acute rumen acidosis. In addition, ensiling lucerne or the most planted and nutritious forage fibre source, reduces plant wastage and enables its major dietary use throughout the year. Lucerne, however, has a high buffering capacity, low water soluble carbohydrates (WSC) content and is rich in highly degradable crude protein (CP) (NRC, 2001; Buxton et al., 2003). As a result, it is more difficult to quickly reduce the silage $\mathrm{pH}$, minimize clostridia growth, proteolysis and heterolytic fermentation, and to improve silage palatability compared to maize silage (McDonald et al., 1991).

Excessive moisture interferes with the rapid establishment of lactic acid-producing bacteria, and promotes the establishment of clostridia bacteria and effluent outflow (Jonsson, 1991; Gordon et al., 1999). On the other hand, a very high pre-ensilage dry matter (DM) will require efficient and mechanized packing to minimize aerobic deterioration. For instance, it has been recommended that lucerne be ensiled with 300 $400 \mathrm{~g} / \mathrm{kg}$ DM in bunker silos, $400-450 \mathrm{~g} / \mathrm{kg}$ DM in tower silos, and $>450 \mathrm{~g} / \mathrm{kg} \mathrm{DM}$ in oxygen-limited silos 
(Ishler et al., 1992). Due to the common and economical use of bunker silos in Iran, it is important that lucerne reaches the recommended DM content before being ensilaged, which usually necessitates wilting. Wilting moist lucerne may increase the lactate to acetate ratio and decrease effluent and spoilage (Whiter \& Kung, 2001; Rizk et al., 2005). However, wilted grasses have an increased silage $\mathrm{pH}$ and a decreased lactic acid percentage (Umana et al., 1991; Gordon et al., 1999). The importance of wilting, molasses and inoculants per se, on the forage nutritive value, is known (Luchini et al., 1997; Whiter \& Kung, 2001; Rizk et al., 2005; Filya et al., 2007; Muck et al., 2007). However, the current information on how all these factors can collectively contribute to improving lucerne silage and rumen biochemistry is inadequate and inconclusive. Such data are needed for optimizing preservation strategies because lucerne is highly nitrogenous. That contributes considerably to diurnal variations in ruminal $\mathrm{pH}$ and consequently, inputs of organic acids, effective fibre and nitrogen $(\mathrm{N})$ fractions differ vastly in the post-feeding degradation rate (Sniffen et al., 1992; Beever, 1993). These factors influence the maintenance energy requirements of ruminal microorganisms, and determine microbial protein yield (NRC, 2001). Our objectives were to determine the major and interactive effects of wilting and the adding molasses and inoculants on the chemical composition of lucerne silage, its in vitro organic matter (OM) digestion and gas production, and its in situ rumen degradation.

\section{Materials and Methods}

A fourth-cut, pre-blooming lucerne crop with an approximate DM content of $200 \mathrm{~g} / \mathrm{kg}$ was harvested for silage on November 25, 2006. The lucerne was ensiled as either fresh upon harvest or wilted to $370 \mathrm{~g}$ $\mathrm{DM} / \mathrm{kg}$. Immediately after harvest the fresh lucerne was chopped with a commercial forage harvester into particles with an average theoretical size of $2.5 \mathrm{~cm}$, and was divided into three portions. The portions were treated with 0,50 or $100 \mathrm{~g}$ of sugar beet molasses $/ \mathrm{kg}$ DM. Each portion was treated with: 1) distilled water and no inoculants, or 2) Ecosyl containing Lactobacillus plantarum MTD-1, $1 \times 10^{6}$ colony forming unit (CFU)/g of fresh forage, or 3) Lalsil containing L. plantarum MA-18/5U, $3 \times 10^{6}$, and Propionibacterium acidipropionici MA-26, $3 \times 10^{6} \mathrm{CFU} / \mathrm{g}$ of fresh forage. The inoculants were dissolved in distilled water before application to the lucerne. The same amount of distilled water was applied when no inoculants were used. The experiment had a $2 \times 3 \times 3$ factorial arrangement of wilting, molasses addition, and inoculant application, respectively, with a total of 18 treatments. The lucerne was ensiled in three replicates for each treatment at the approximate amount of $2.5-3 \mathrm{~kg}$ forage in 3-L laboratory PVC silos with a sink at the bottom to permit waste and effluent outflow. Upon filling, the silos were packed with a presser and capped tightly to minimize aerobic fermentation. All silos were transferred to the animal nutrition laboratory (Isfahan University of Technology) until being opened for sampling after $90 \mathrm{~d}$ of preservation at room temperature $\left(20\right.$ to $\left.23^{\circ} \mathrm{C}\right)$.

Immediately after opening the silos, the silage $\mathrm{pH}$ was measured using silage extracts, and a fresh silage sample was collected and kept at $-20^{\circ} \mathrm{C}$ pending laboratory analysis. A silage extract was obtained after mixing $20 \mathrm{~g}$ of fresh silage with $180 \mathrm{~mL}$ of distilled water for $30 \mathrm{~s}$ in a mixer. The extract was filtered, using two filter papers, and the filtrate was kept to be used for organic acid and ammonia measurements. The silage DM was determined after being oven-dried for $72 \mathrm{~h}$ at $60{ }^{\circ} \mathrm{C}$. The dried samples were ground to pass through a $1 \mathrm{~mm}$ screen using a Wiley mill (Arthur H. Thomas Co., Philadelphia). Organic matter was determined by ashing it at $550^{\circ} \mathrm{C}$ for $12 \mathrm{~h}$. The ground samples were analyzed for CP (1030 Micro Kjeltec Auto Analyzer, method 984.13; AOAC, 2000), neutral detergent fibre (NDF) (Van Soest et al., 1991; using heat-stable $\alpha$-amylase and sodium sulphite) and acid detergent fibre (ADF) (AOAC, 2000). To determine lactic acid in silage extracts, methyl esters were formed and lactic acid and volatile fatty acid (VFA) concentrations were determined, using gas chromatography $(0.25 \times 0.32$, id of $0.3 \mu \mathrm{m}$ WCOT Fused Silica Capillary, CHROMPACK CP. 9002, Model No. CP-9002 Serial No. 9477 B, Vulcanusweg 259, AM DELFT, the Netherlands), according to Khorvash et al. (2005).

Water-soluble carbohydrates were determined, by using the phenol-sulphuric acid method, following the Dubois et al. (1956) technique. Briefly, $10 \mathrm{~g}$ of fresh silage was mixed with $90 \mathrm{~mL}$ of distilled water for $2 \mathrm{~min}$ and centrifuged at $2000 \times \mathrm{g}$ for $10 \mathrm{~min}$. The supernatant was diluted 10 times, and $1 \mathrm{~mL}$ of the diluted liquid was transferred to another tube to which $5 \mathrm{~mL}$ of concentrated sulphuric acid and $0.15 \mathrm{~mL}$ of $800 \mathrm{~g} / \mathrm{kg}$ phenol solution were added. The reactions were cooled down and read on a spectrophotometer at a wavelength of $470 \mathrm{~nm}$. Glucose and xylose were used as preparing standards. Ammonia concentrations were measured according to the method of Filya (2003). 
The amount of gas produced from the silage samples was measured in serum bottles according to the method of Fedorak \& Hurdy (1983). Firstly, $300 \mathrm{mg}$ of finely-ground silage (1 $\mathrm{mm}$ screen size) were weighed into $50 \mathrm{~mL}$ sterile serum bottles. A $20 \mathrm{~mL}$ mixture of rumen fluid and artificial buffer at a ratio of $1: 2$ (McDougall, 1948), was added to each bottle and kept under continuous $\mathrm{CO}_{2}$ flow. The rumen fluid was obtained $2 \mathrm{~h}$ after the morning feeding from two rumen fistulated sheep fed a total mixed ration of $600 \mathrm{~g}$ concentrate and $400 \mathrm{~g}$ lucerne hay $/ \mathrm{kg} \mathrm{DM}$. The rumen content was filtered through four layers of cheesecloth to extract the filtrate to a warm flask containing $\mathrm{CO}_{2}$, before being transfer to the laboratory. To avoid microbial heat shock, the bottles were warmed up to $39^{\circ} \mathrm{C}$ for $30 \mathrm{~min}$ before and while adding the mixture of rumen fluid and buffer to the sample under $\mathrm{CO}_{2}$. The bottles were tightly capped and placed in an incubator at $39{ }^{\circ} \mathrm{C}$, shaking at 120 rounds per min. For each batch in the in vitro study three blank bottles, containing only the rumen fluid preparations without any sample were used to adjust the results for gas originating from the rumen fluid. The amount of gas released from silage fermentation was recorded at 2, 4, 6, 8, 12, 16, 24, 36 and $48 \mathrm{~h}$ post-incubation, based on the water movement in the apparatus (Fedorak \& Hurdy 1983). The gas volume was calculated by using the formula, $\mathrm{V}=(\mathrm{Vt}-\mathrm{Vb}) \times 100 / \mathrm{W}$, where $\mathrm{V}=$ the net volume of gas produced per $\mathrm{g} \mathrm{DM}$ of lucerne silage sample; $\mathrm{Vt}=\mathrm{mL}$ of total gas produced in sample bottles; $\mathrm{Vb}=\mathrm{mL}$ of average total gas produced in blank bottles; $\mathrm{W}=\mathrm{g}$ of the total sample weight. The OM digestibility was determined according to Menke et al. (1979) using the calculated V value, and the CP and ash concentrations of each sample.

Three rumen-cannulated rams were used to study the in situ rumen degradation of the lucerne silage. The sheep were fed lucerne for three weeks prior to the in situ study and were cared for according to the guidelines if the Iranian Animal Council of Animal Care (1995). Dried silage samples were ground to pass through a $1 \mathrm{~mm}$ screen, using a Wiley mill (Arthur H. Thomas Co., Philadelphia), and were weighed into polyester nylon bags $\left(10-20 \mathrm{mg} / \mathrm{cm}^{2}\right.$, Vanzant et al., 1998). The nylon bags (pore size $=41.6-52.0 \mu \mathrm{m}$ ) were sealed and soaked in $37{ }^{\circ} \mathrm{C}$ water for $30 \mathrm{~min}$ before ruminal incubation. After $24 \mathrm{~h}$ of incubation, the nylon bags were taken out of the rumen and rinsed under tap water until the rinse water was clear. The in situ rumen DM degradation was calculated based on the difference in weights of the nylon bags before and after ruminal incubation.

Data were analyzed by using the Mixed Procedure of SAS (2003) with fixed effects of wilting, molasses addition, inoculant application, and their two-way and three-way interactions. Least square means were estimated using the Maximum Likelihood Method and denominator degrees of freedom were calculated using the Kenward-Roger method. For repeated measures of the in vitro OM digestion and gas production, the final statistical models included the fixed effects of molasses, inoculants at different hours of incubation, and their interactions as well as the random effect of molasses $\times$ inoculants. Compound symmetry was the covariance structure adopted for repeated measures analysis of the in vitro experiment. The CONTRAST statement of SAS was used to calculate $P$ values for the linear and quadratic effects of molasses addition to lucerne. The PDIFF option of SAS, with the multiple range Tukey test, was used to separate least square means and the SLICE option was used to separate means within each post-incubation hour. The significant differences were declared at $P \leq 0.05$.

\section{Results}

Wilting the lucerne before ensiling increased $(P<0.0001)$ the silage DM content, tended to decrease $\mathrm{CP}(P=0.07)$ and decreased silage NDF $(P=0.01)$ and ADF $(P=0.01)$ contents (Table 1). Adding molasses to the lucerne crop increased the silage DM content linearly $(P=0.002)$ in fresh lucerne and quadratical $(P=0.02)$ in wilted lucerne. Molasses had a quadratic effect on the silage NDF content $(P=0.0007)$ so that the NDF content increased at $50 \mathrm{~g}$ molasses $/ \mathrm{kg}$ but not at $100 \mathrm{~g} / \mathrm{kg}$ (Table 1). Wilting reduced the concentration of acid detergent insoluble nitrogen (ADIN) of the silage $(P<0.01)$, but such a reduction did not occur when molasses was added at $50 \mathrm{~g} / \mathrm{kg}$. The silage lactic acid content dropped $(P<0.0001)$ when the lucerne was wilted before being ensilaged. Molasses did not affect the lactic acid content of the silage when wilted before being ensiled, but decreased it linearly when fresh lucerne was ensiled (Table 1). Wilting caused a reduction in the silage ammonia and acetate concentrations $(P<0.0001)$ and an increase in the WSC concentration $(P<0.0001)$. Adding molasses to lucerne increased the WSC content of the silage in both withed and unwilted silage (Table 1). The silage $\mathrm{pH}$ was lower when the lucerne was not wilted before being ensilaged. Adding $50 \mathrm{~g} / \mathrm{kg}$ of molasses lowered the silage $\mathrm{pH}$ in wilted lucerne, but for fresh lucerne, the silage $\mathrm{pH}$ decreased only when $100 \mathrm{~g}$ molasses $/ \mathrm{kg}$ was added (Table 1). Adding both levels of molasses to 
wilted lucerne increased the acetate content and decreased the lactate to acetate ratio, but this effect was not observed in freshly ensiled lucerne. Wilting, molasses addition and their interaction did not affect the silage ash content and its $24 \mathrm{~h}$ in situ DM degradation.

The inoculant type and its interaction with the wilting process did not affect the levels of DM and CP in the silage (Table 2). However, the inoculants interacted with the wilting process by affecting the contents of fibre, ADIN, acetate, ammonia, WSC and in situ DM degradation of the silage and silage $\mathrm{pH}$. Applying both inoculants to wilted but not to fresh lucerne decreased $(P<0.0001)$ the percentage of ADIN in the silage. In wilted lucerne, only Ecosyl decreased the silage ADF concentration, but in fresh lucerne both inoculants decreased the silage ADF concentration (Table 2). Adding Lalsil, but not Ecosyl, to wilted lucerne reduced $(P<0.01)$ the silage acetate percentage while adding both Ecosyl and Lalsil to fresh lucerne reduced $(P<0.01)$ the silage acetate percentage. Neither inoculants affected the silage ammonia content of fresh lucerne, but Lalsil decreased it in wilted lucerne (Table 2). Adding inoculants to wilted lucerne increased the silage WSC concentration with Lalsil exhibited a more pronounced effect than Ecosyl. However, the inoculants had no effects on the silage WSC concentration when lucerne was ensiled unwilted. Silage $\mathrm{pH}$ decreased $(P<0.01)$ and increased $(P=0.05)$ when Lalsil was added to wilted and fresh lucerne, respectively. Inoculants enhanced the in situ rumen degradation of the silage DM. The type of inoculant interacted with the wilting treatment on rumen degradation of silage DM, viz. Lalsil increased it in wilted lucerne and Ecosyl in fresh lucerne.

There were no interactions between molasses and the inoculants on silage $\mathrm{pH}$, or on the concentrations of DM, CP, ADF, lactate and ash (Table 3). Adding 50 and $100 \mathrm{~g} / \mathrm{kg}$ of molasses to lucerne before ensiling it, linearly increased the silage acetate concentration in the absence of the inoculants. In the presence of Ecosyl, adding $50 \mathrm{~g} / \mathrm{kg}$ of molasses increased silage acetate, but $100 \mathrm{~g}$ molasses $/ \mathrm{kg}$ decreased the acetate concentration, although it was still higher than when no molasses was added. Molasses without inoculants did not affect the silage ammonia, whereas 50 and $100 \mathrm{~g}$ molasses $/ \mathrm{kg}$ with Ecosyl and only $100 \mathrm{~g}$ molasses/kg with Lalsil decreased the silage ammonia (Table 3). With inoculants, molasses linearly increased silage WSC concentrations.

Adding $100 \mathrm{~g}$ molasses $/ \mathrm{kg}$ to wilted lucerne improved the in vitro silage OM digestibility at $6 \mathrm{~h}(P=$ $0.10), 8 \mathrm{~h}(P=0.04), 36 \mathrm{~h}(P=0.10)$ and $48 \mathrm{~h}(P=0.08)$ (Figure 1$)$.

Without molasses, Lalsil inoculated silages had a lower gas production at 12,16 and $24 \mathrm{~h}$ postincubation (Figure 2a, $P=0.04$ ) than with the inoculant. Molasses, especially at $100 \mathrm{~g} / \mathrm{kg}$ increased the total gas production and modulated the negative effect of inoculants on gas production $(P<0.0001)$. An interaction $(P<0.01)$ existed between the molasses, inoculants and incubation hour on in vitro gas production. During the incubation time, the gas production increased by the inoculants as the molasses was added to the wilted lucerne (Figures 2a, b, c).

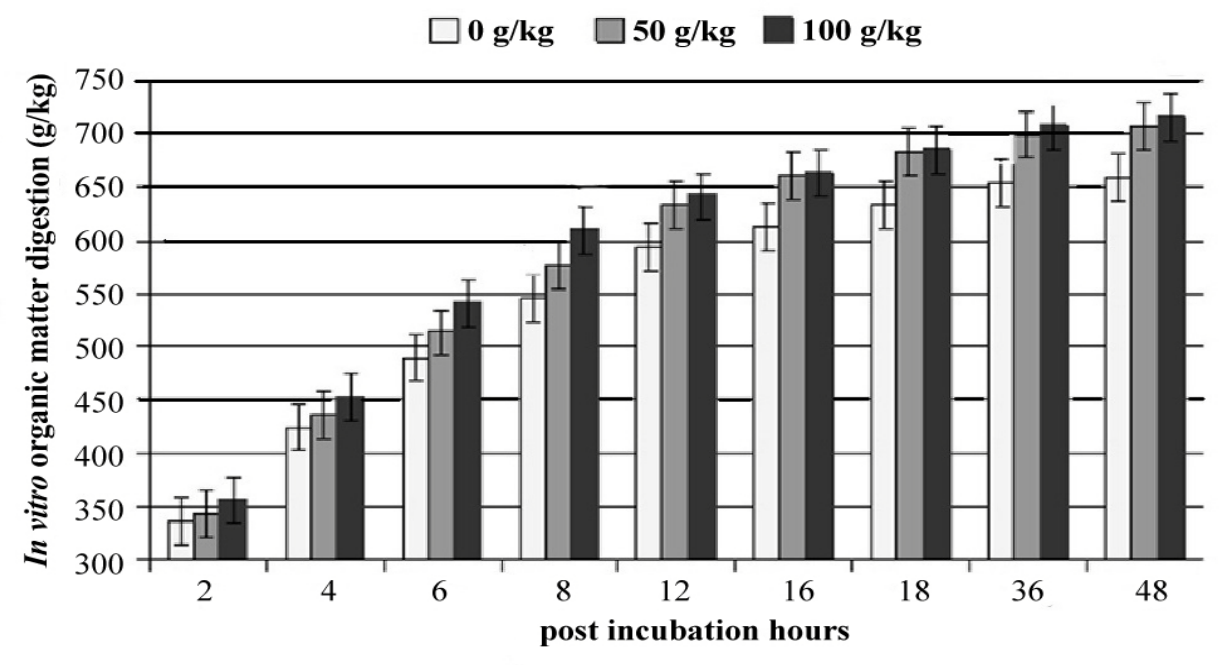

Figure 1 Effects of molasses addition at 0,50 or $100(\mathrm{~g} / \mathrm{kg})$ on wilted lucerne before ensilage and on in vitro silage organic matter degradation. For hours 6 and 36, $P=0.10$; for hour $8, P=0.04$; for hour 48, $P=0.08$. 
Table 1 Effects of wilting (W) and molasses addition (M), after ensilage, on nutrient composition and $24 \mathrm{~h}$ in situ degradation of lucerne silage

\begin{tabular}{|c|c|c|c|c|c|c|c|c|c|c|c|}
\hline \multirow{3}{*}{ Molasses $(\mathrm{g} / \mathrm{kg})=$} & \multicolumn{3}{|c|}{ Wilted } & \multicolumn{3}{|c|}{ Fresh } & \multirow{3}{*}{ SE } & \multicolumn{4}{|c|}{$P$-value } \\
\hline & \multirow{2}{*}{0} & \multirow{2}{*}{50} & \multirow{2}{*}{100} & \multirow{2}{*}{0} & \multirow{2}{*}{50} & \multirow{2}{*}{100} & & \multirow{2}{*}{$\mathrm{W}$} & \multicolumn{2}{|c|}{$\mathrm{M}^{1}$} & \multirow{2}{*}{$\mathrm{W} \times \mathrm{M}$} \\
\hline & & & & & & & & & Lin & Quad & \\
\hline Dry matter $(\mathrm{DM}, \mathrm{g} / \mathrm{kg})$ & 377 & 374 & 387 & 211 & 217 & 221 & 3 & $<.0001$ & 0.002 & 0.02 & 0.20 \\
\hline Crude protein (g/kg DM) & 225 & 212 & 208 & 225 & 219 & 214 & 2 & 0.07 & $<.0001$ & 0.0001 & 0.55 \\
\hline Neutral detergent fibre (g/kg DM) & 294 & 317 & 301 & 304 & 324 & 317 & 5 & 0.01 & 0.05 & 0.0007 & 0.65 \\
\hline Acid detergent fibre (g/kg DM) & 222 & 231 & 220 & 231 & 233 & 229 & 4 & 0.04 & 0.65 & 0.53 & 0.61 \\
\hline Acid detergent insoluble $\mathrm{N}(\mathrm{g} / \mathrm{kg} \mathrm{N})$ & 108 & 131 & 107 & 120 & 130 & 110 & 2.5 & $<0.0001$ & 0.8 & 0.0001 & 0.03 \\
\hline Lactate (g/kg DM) & 58 & 58 & 59 & 99 & 97 & 95 & 0.8 & $<0.0001$ & 0.20 & 0.18 & 0.03 \\
\hline Acetate $(\mathrm{g} / \mathrm{kg} \mathrm{DM})$ & 11.9 & 21.5 & 19.3 & 27.3 & 25.4 & 27.7 & 0.8 & $<0.0001$ & $<0.0001$ & $<0.0001$ & $<0.0001$ \\
\hline Lactate : acetate & 5.0 & 3.00 & 3.23 & 3.65 & 3.84 & 3.57 & 0.18 & 0.50 & $<0.0001$ & $<0.0001$ & $<0.0001$ \\
\hline Butyrate (g/kg DM) & 1.0 & 5.8 & 3.1 & 8.2 & 5.4 & 4.0 & 2.2 & 0.17 & 0.66 & 0.99 & 0.21 \\
\hline Ammonia-N ( $\mathrm{g} / \mathrm{kg}$ total $\mathrm{N})$ & 214 & 224 & 205 & 360 & 340 & 329 & 12.05 & $<.0001$ & 0.64 & 0.60 & 0.14 \\
\hline Ash $(g / k g ~ D M)$ & 125 & 125 & 130 & 124 & 124 & 125 & 1.8 & 0.17 & 0.12 & 0.46 & 0.41 \\
\hline Water soluble carbohydrates (g/kg DM) & 7.6 & 9.4 & 11.4 & 5.5 & 6.1 & 7.1 & 0.6 & $<.0001$ & 0.0002 & 0.001 & 0.22 \\
\hline $\mathrm{pH}$ & 4.86 & 4.73 & 4.72 & 4.67 & 4.63 & 4.60 & 0.03 & $<.0001$ & .0005 & .0003 & 0.22 \\
\hline In situ DM degradation (g/kg DM) & 820 & 817 & 828 & 825 & 820 & 828 & 3 & 0.33 & 0.15 & 0.81 & 0.74 \\
\hline
\end{tabular}

${ }^{1} P$ values are given for linear (Lin) and quadratic (Quad) trends of the effect of molasses addition at 0,50 and $100(\mathrm{~g} / \mathrm{kg})$. 
Table 2 Effects of wilting (W), with or without inoculants ${ }^{1}$ (I), on the nutrient composition and in situ rumen degradability of lucerne silage

\begin{tabular}{|c|c|c|c|c|c|c|c|c|c|c|}
\hline \multirow[b]{2}{*}{ Inoculant $=$} & \multicolumn{3}{|c|}{ Wilted } & \multicolumn{3}{|c|}{ Fresh } & \multirow{2}{*}{ SE } & \multicolumn{3}{|c|}{$P$-value } \\
\hline & No & Ecosyl & Lalsil & No & Ecosyl & Lalsil & & $\mathrm{W}$ & I & $\mathrm{W} \times \mathrm{I}$ \\
\hline Dry matter $(\mathrm{DM}, \mathrm{g} / \mathrm{kg})$ & 380 & 381 & 377 & 214 & 221 & 214 & 3 & $<.0001$ & 0.20 & 0.50 \\
\hline Crude protein (g/kg DM) & 217 & 211 & 216 & 216 & 223 & 219 & 2 & 0.07 & 0.94 & 0.12 \\
\hline Neutral detergent fibre (g/kg DM) & 316 & 302 & 295 & 314 & 308 & 323 & 5 & 0.01 & 0.16 & 0.01 \\
\hline Acid detergent fibre ( $\mathrm{g} / \mathrm{kg} \mathrm{DM})$ & 233 & 224 & 236 & 236 & 225 & 212 & 4 & 0.04 & 0.03 & 0.002 \\
\hline Acid detergent insoluble $\mathrm{N}(\mathrm{g} / \mathrm{kg} \mathrm{N})$ & 124 & 118 & 104 & 128 & 117 & 123 & 3.05 & 0.002 & $<.0001$ & 0.001 \\
\hline Lactate $(\mathrm{g} / \mathrm{kg} \mathrm{DM})$ & 58 & 59 & 58 & 96 & 96 & 98 & 0.8 & $<.0001$ & 0.33 & 0.14 \\
\hline Acetate $(\mathrm{g} / \mathrm{kg} \mathrm{DM})$ & 20.6 & 19.6 & 12.5 & 30.3 & 25.0 & 25.1 & 0.8 & $<.0001$ & $<.0001$ & $<.001$ \\
\hline Lactate : acetate & 3.02 & 3.28 & 5.06 & 3.24 & 3.89 & 3.93 & 1.8 & 0.50 & $<.0001$ & $<.0001$ \\
\hline Butyrate (g/kg DM) & 2.5 & 7.4 & ND & 9.6 & 3.5 & 4.6 & 2.2 & 0.17 & 0.21 & 0.05 \\
\hline Ammonia-N (g/kg total $\mathrm{N})$ & 229 & 242 & 171 & 351 & 331 & 349 & 12.05 & $<.0001$ & 0.0003 & $<.0001$ \\
\hline Ash (g/kg DM) & 130 & 127 & 123 & 124 & 120 & 129 & 1.8 & 0.17 & 0.16 & 0.0007 \\
\hline Water-soluble carbohydrates (g/kg DM) & 6.3 & 8.9 & 13.3 & 6.0 & 7.2 & 5.5 & 0.6 & $<.0001$ & $<.0001$ & $<.0001$ \\
\hline $\mathrm{pH}$ & 4.88 & 4.80 & 4.64 & 4.58 & 4.63 & 4.69 & 0.03 & $<.0001$ & 0.05 & $<.0001$ \\
\hline In situ $\mathrm{DM}$ degradation (g/kg DM) & 815 & 816 & 840 & 816 & 832 & 817 & 3 & 0.33 & 0.002 & $<0.0001$ \\
\hline
\end{tabular}

\footnotetext{
${ }^{1}$ Ecosyl contained Lactobacillus plantarum MTD1; Lalsil contained Lactobacillus plantarum MTD1 and Propionibacterium acidipropionici MA26.
} 
Table 3 Effects of molasses addition (M), with or without inoculants ${ }^{1}(\mathrm{I})$, on the nutrient composition and in situ rumen degradability

\begin{tabular}{|c|c|c|c|c|c|c|c|c|c|c|c|c|c|}
\hline \multicolumn{2}{|l|}{ Inoculant $=$} & \multicolumn{2}{|l|}{ No } & \multicolumn{3}{|c|}{ Ecosyl } & \multicolumn{3}{|c|}{ Lalsil } & \multirow{2}{*}{ SE } & \multicolumn{3}{|c|}{$P$-value } \\
\hline Molasses $(\mathrm{g} / \mathrm{kg})=$ & 0 & 50 & 100 & 0 & 50 & 100 & 0 & 50 & 100 & & M & I & $\mathrm{M} \times \mathrm{I}$ \\
\hline Dry matter (DM, g/kg) & 289 & 297 & 296 & 298 & 299 & 289 & 303 & 306 & 303 & 3.6 & $<0.01$ & 0.20 & 0.24 \\
\hline Crude protein (g/kg DM) & 223 & 221 & 230 & 216 & 216 & 213 & 211 & 213 & 209 & 2.4 & $<0.001$ & 0.94 & 0.41 \\
\hline Neutral detergent fibre (g/kg DM) & 301 & 325 & 291 & 306 & 318 & 291 & 290 & 320 & 317 & 6.1 & $<0.001$ & 0.16 & 0.02 \\
\hline Acid detergent fibre (g/kg DM) & 233 & 238 & 232 & 229 & 229 & 216 & 217 & 230 & 227 & 4.9 & 0.12 & 0.03 & 0.18 \\
\hline Acid detergent insoluble $\mathrm{N},(\mathrm{g} / \mathrm{kg} \mathrm{N})$ & 113 & 142 & 123 & 124 & 126 & 102 & 104 & 123 & 113 & 3.7 & $<0.0001$ & $<0.0001$ & $<0.0001$ \\
\hline Lactate (g/kg DM) & 79 & 77 & 75 & 78 & 77 & 77 & 78 & 78 & 79 & 1 & 0.39 & 0.33 & 0.16 \\
\hline Acetate $(\mathrm{g} / \mathrm{kg} \mathrm{DM})$ & 22.4 & 24.7 & 29.2 & 18.9 & 26.2 & 21.9 & 17.6 & 19.5 & 19.5 & 1 & $<0.0001$ & $<.01$ & $<0.01$ \\
\hline Lactate : acetate & 3.72 & 3.12 & 2.56 & 4.21 & 3.01 & 3.51 & 5.23 & 4.13 & 4.12 & 2.2 & $<0.0001$ & $<.01$ & 0.22 \\
\hline Butyrate (g/kg DM) & 11.5 & 4.4 & 2.3 & 0.5 & 10.3 & 5.5 & 1.9 & 2.1 & 3.0 & 2.7 & 0.67 & 0.21 & 0.03 \\
\hline Ammonia-N (g/kg total $\mathrm{N})$ & 283 & 300 & 287 & 315 & 272 & 273 & 262 & 278 & 240 & 14.7 & 0.01 & 0.003 & 0.004 \\
\hline Ash (g/kg DM) & 124 & 125 & 132 & 124 & 124 & 122 & 126 & 124 & 129 & 2.2 & 0.12 & 0.16 & 0.20 \\
\hline Water soluble carbohydrates (g/kg DM) & 7.2 & 5.3 & 6.0 & 5.8 & 8.7 & 9.7 & 6.8 & 9.3 & 12.1 & 0.7 & 0.001 & $<.01$ & 0.008 \\
\hline $\mathrm{pH}$ & 4.79 & 4.70 & 4.70 & 4.80 & 4.66 & 4.68 & 4.70 & 4.69 & 4.60 & 0.04 & 0.001 & 0.05 & 0.36 \\
\hline In situ DM degradation (g/kg DM) & 806 & 819 & 821 & 821 & 819 & 837 & 841 & 819 & 826 & 3.6 & 0.05 & $<.01$ & $<0.01$ \\
\hline
\end{tabular}

${ }^{1}$ Ecosyl contained Lactobacillus plantarum MTD1; Lalsil contained Lactobacillus plantarum MTD1 and Propionibacterium acidipropionici MA26. 


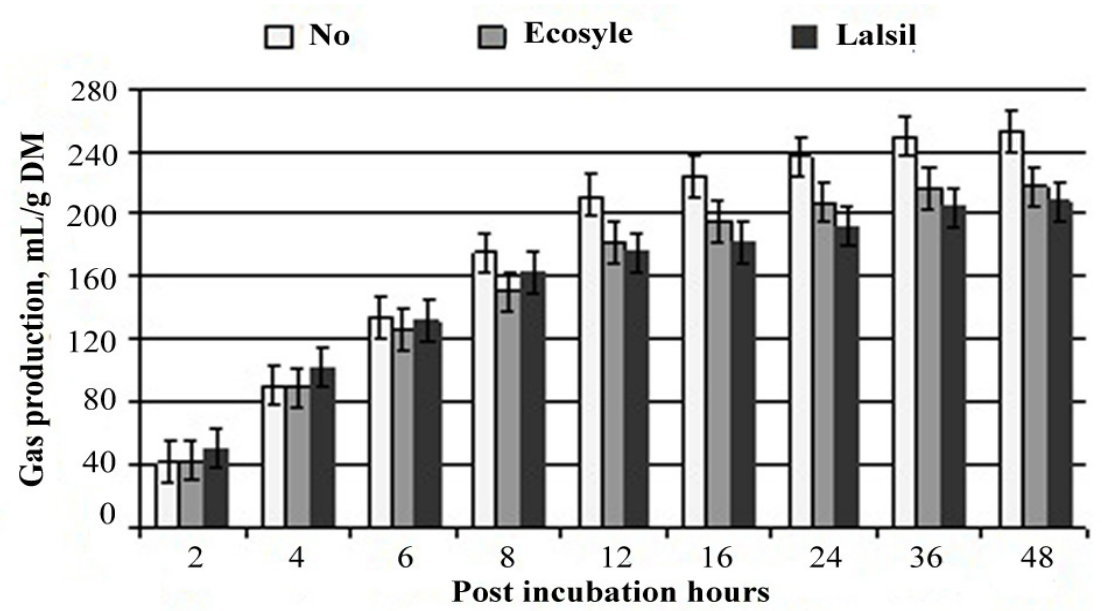

a) $0(\mathrm{~g} / \mathrm{kg})$ molasses

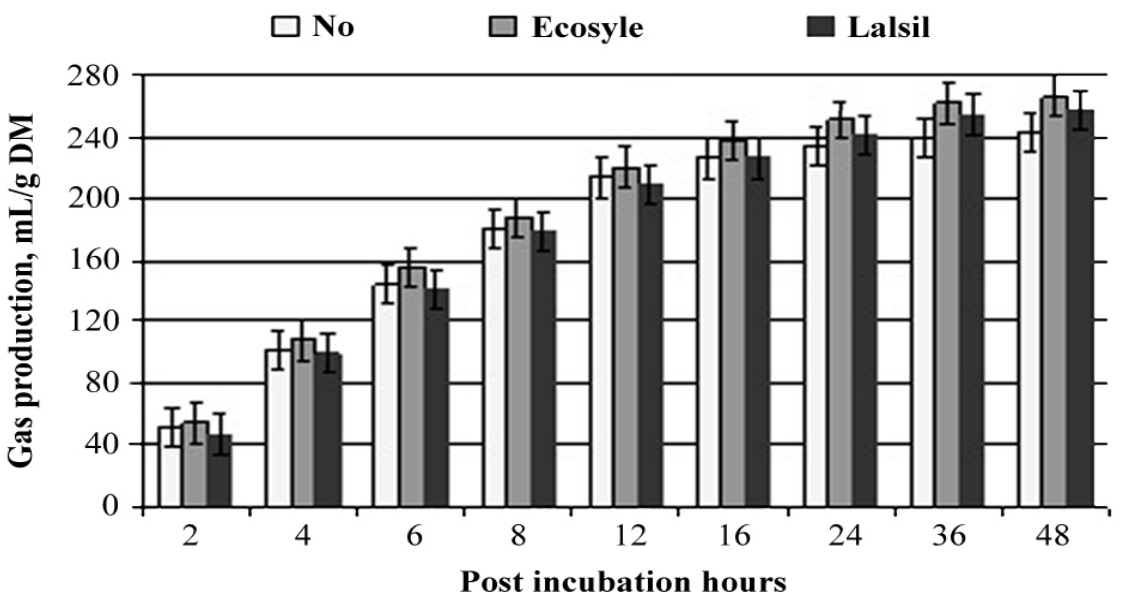

b) $50(\mathrm{~g} / \mathrm{kg})$ molasses

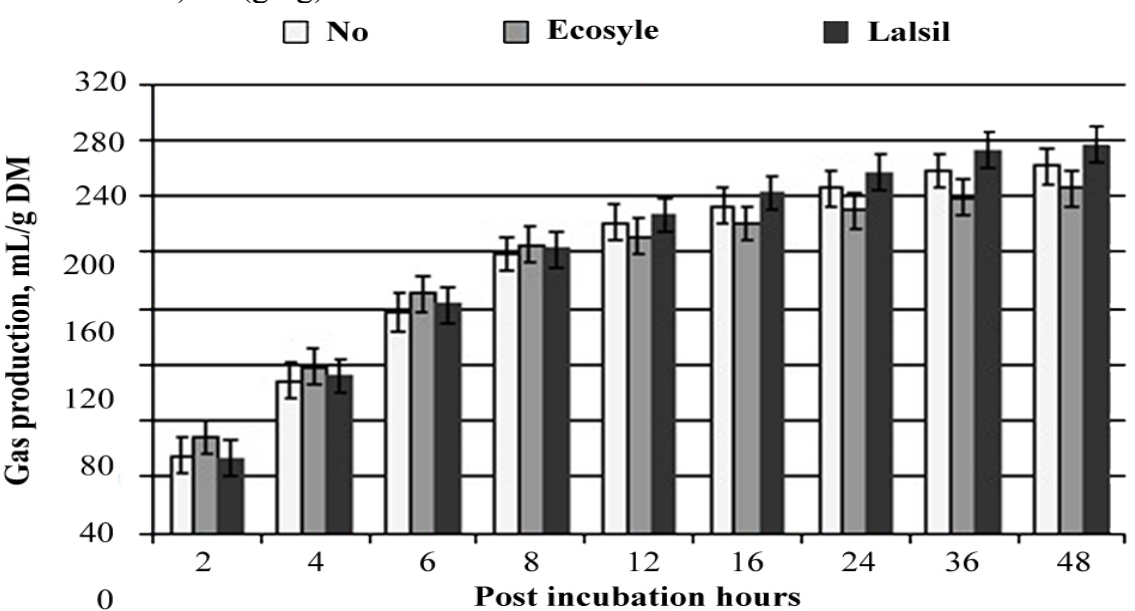

c) $100(\mathrm{~g} / \mathrm{kg})$ molasses

Figure 2 Effects of ensilage with (either Ecosyl or Lalsil) or without (no) inoculants on in vitro gas production of wilted lucerne silage ensiled with 0 (a), 50 (b), or 100 (c) g molasses $/ \mathrm{kg}$. For the effect of hour, $P=0.05$; for the effect of molasses $\times$ inoculants $\times$ hour, $P<0.0001$.

\section{Discussion}

The current study demonstrates the effects of wilting lucerne and adding molasses and inoculants on lucerne silage characteristics in the laboratory. Nitrogenous forages such as lucerne require unique preservation strategies, because of they are deficient in readily-fermentable carbohydrates and contain 
high concentrations of degradable protein (Beever, 1993; NRC, 2001). Although ensiling reduces plant and nutrient wastage and ensures the continuous supply of palatable forage fibre for livestock production (Muck \& Pitt, 1993; Kowsar et al., 2008), the process solubilizes proteins and challenges an efficient microbial assimilation of nitrogenous compounds, high-energy phosphate bounds and carbon skeletons into a microbial mass. Hence, the altered lucerne fermentation characteristics during ensilage will have a high impact in the rumen on the synchrony of energy and $\mathrm{N}$ release, ammonia production and absorption, and fibre digestion (NRC, 2001).

The wilting process and molasses aim to limit clostridia growth and promote lactate production during the initial hours of fermentation in the silo (Weinberg et al., 1999; Filya, 2003). The increased silage $\mathrm{pH}$ and reduced lactate content by wilting agree with the literature (Gordon et al., 1999) and suggest an initial decline in the extent of DM fermentation. This data is in line with the increased silage WSC and decreased fibre content due to wilting.

The findings that Lalsil increased the silage $\mathrm{pH}$ from 4.58 to 4.69 in fresh lucerne and decreased it from 4.88 to 4.64 in wilted lucerne suggest that at a higher crop DM content, inoculants can produce a more homolactic fermentation and lower the silage $\mathrm{pH}$ more rapidly and efficiently during the earlier stages of ensiling. This data and our findings support the notion that wilting low DM lucerne can lead inoculants to establish the homolactic fermentation quicker, which is consistent with the findings of Wither \& Kung (2001). This notion is supported by the fact that Lalsil decreased silage acetate by $40 \%$ in wilted lucerne but only by $16 \%$ in fresh lucerne. For barley crop silage (Hristov \& McAllister, 2002), all three types of inoculants used, could reduce the silage $\mathrm{pH}$ on wilted crop, but two thirds of inoculants were ineffective on unwilted crops. Furthermore, Sheperd et al. (1995), Filya et al. (2007) and Kozelov et al. (2008) observed a lower $\mathrm{pH}$ in silages treated with microbial inoculants. It may be attributed to the lower production of ammonia-N and acetate as well as their lower buffering effects in inoculated silages.

Adding molasses to the wilted lucerne increased the acetate concentration and decreased the lactate to acetate ratio, which suggests that supplementing extra sugar to wilted forage stimulates heterofermentative lactic acid bacteria and allows them to have a more prominent role in fermenting sugars to wasteful end-products. This is in agreement with the results of Jones et al. (1992). Gül et al. (2008) reported that adding molasses to grass silage increased the acetate concentration. These researchers postulated that the addition of molasses to silage caused hetero-fermentative fermentation or the conversion of lactate to acetate, and thereby an increased acetate concentration in silage. However, enterobacteriaceae are the main acetate-producing bacteria in silage and they strictly depend on fermentable carbohydrates for anaerobic growth (Buxton et al., 2003), so added molasses can stimulate their growth during fermentation phases.

The decreased silage fibre content may be a consequence of reduced effluent production and the extent of fermentation of the soluble fractions following the wilting process (Luchini et al., 1997). Reduced silage ADIN by wilting could be due to the decreased silage ADF content and ensilage temperature, and decreased initial fermentation likely via reduced clostridial and enterobacterial growth. This is in agreement with the decreased silage ammonia and acetate concentrations, which usually increase during heterolytic reactions in high moisture situations (McDonald et al., 1991).

Silage ammonia is reduced when plant enzyme activity, nitrate reduction and proteolysis decrease (Umana et al., 1991; Whiter \& Kung, 2001). These reductions can occur at a higher crop DM content, which would explain the decreased silage ammonia levels in the wilted lucerne silage in the present study. Molasses and inoculants seemed to have an additive effect on reducing silage ammonia, acetate and increasing the WSC content of the silages, which suggests a decreased lucerne proteolysis by elevated external WSC supply and a hastened lactic acid bacteria settlement. Jones et al. (1992) reviewed some studies and concluded that in grass crops with a low WSC content, inoculants will not improve silage quality due to a limitation of substrates. These researchers reported that the combination of inoculants and sugar additively increased lactate, lactate to acetate ratio and residual sugar concentration of lucerne silage, indicating a more homolactic fermentation than only a sugar and inoculant addition. In addition, it was reported that treating lucerne crops with cellulose increased the sugar content and the improved fermentation characteristics of lucerne silage and the addition of inoculants enhanced this effect (Nadeau et al., 2000; Kozelov et al., 2008). These data indicated that the addition of microbial inoculants can increase the production of lactic acid and the rate of $\mathrm{pH}$ decline only when sufficient fermentable sugars are available (Nadeau et al., 2000). 
The Lalsil inoculant reduced the silage ammonia in wilted but not in fresh lucerne, supporting the premise that proteolysis can be more effectively limited in the presence of certain microbial additives. Wither \& Kung (2001) showed that microbial inoculation reduced the accumulation of ammonia in higher DM silage than in low DM silage.

Silages treated with Lalsil, containing lactate and propionate producing bacteria, had a lower $\mathrm{pH}$, acetate, ADF, ADIN and ammonia content and higher content of WSC and lactate to acetate ratio than Ecosyl-inoculated silages, which contain only lactate producing bacteria at a high DM content.

The improved responses in silages treated with Lalsil than Ecosyl might be attributed to the greater number of lactic acid bacteria that could dominate in the fermentation phase of ensiling. Also, in most cases, interactions between propionate and lactate-producing bacteria have been observed in co-cultures (Jimeno et al., 1995). Improved fermentation of Lalsil-inoculated silages compared to Ecosyl-treated silages could be attributed to these synergetic relationships. In addition to a better fermentation quality observed with Lalsil, inoculants containing propionate and lactate-producing bacteria might improve the aerobic stability of silages. However, to our knowledge there are limited reports on the ability of these kinds of microbial inoculants to improve the aerobic stability of lucerne silage.

No overall effects of the wilting process and molasses addition on the $24 \mathrm{~h}$ degradation of rumen silage DM indicate that changes in the nutrient composition of lucerne during wilting and ensilage had an impact on the access of the microorganisms to and digestion of DM in the rumen. On the other hand, altered prevalent microbial proliferation and likely activity during ensilage by applying inoculants to lucerne crops could increase rumen DM disappearance. Lalsil and Ecosyl were effective in enhancing DM disappearances of wilted and fresh lucerne, respectively. This data suggests that wilting influences the silage digestion response to inoculants.

The increased in vitro gas production by the adding of molasses agrees with previous reports on grass and cereal silages (Charmley et al., 1996) and can be explained by the higher silage WSC content and increased carbohydrate fermentation. Similar effects on increased VFA production in sheep fed molasses-treated corn silage have been shown (Donmez et al., 2003). An increased gas production has been related to improved silage quality (Hetta et al., 2007), which would also determine the microbial access to fermentable carbohydrates in the rumen. Lower gas production in silages treated with Lalsil and without molasses agrees with results of Muck et al. (2007) who found that silages treated with inoculants generally produced less gas per unit of incubated DM than the control silages.

The finding that certain inoculants enhanced lucerne silages in situ degradability but did not affect its in vitro $\mathrm{OM}$ digestion and gas production may suggest a superior action of inoculants in the real ruminal environment. For instance, ensilage with $L$. plantarum, present in both inoculants in the current study, has been shown (Zhang et al., 2000) to increase the D-isomer of lactate which is metabolized more slowly than its L-isomer (Giesecke \& Stangassinger 1980). Thus, it can be inferred that lactate and other by- or end-products of ensilage are metabolized more effectively under the dynamic in situ rumen conditions than in batch cultures of the in vitro laboratory bottles where some digestion products can easily accumulate. This data proposes the important collective effects of molasses and inoculants on lucerne ensilage quality and rumen fermentation patterns, which merit further in vivo studies using highproducing lactating cows.

\section{Conclusions}

Wilting lucerne increased silage $\mathrm{DM}, \mathrm{pH}$ and WSC concentration, tended to decrease CP level, and decreased silage ammonia, lactate and acetate concentrations, but did not affect butyrate content and the lactate to acetate ratio in the silage. Wilting reduced silage ADIN in the absence of molasses. Molasses decreased silage lactate in fresh lucerne and increased WSC regardless of wilting. The effect of molasses on silage $\mathrm{pH}$ depended on wilting. Inoculants decreased silage ADIN and ADF levels in wilted and fresh lucerne, respectively. The inoculants consistently increased the $24 \mathrm{~h}$ rumen degradation of the silage but their effects on silage acetate, ammonia, and rumen degradation depended on wilting. In the absence of inoculants, molasses increased silage acetate. Molasses, at $100 \mathrm{~g} / \mathrm{kg}$, improved the in vitro silage digestion at $6,8,36$, and $48 \mathrm{~h}$ post-incubation and counteracted the negative effect of inoculants alone on gas production. It was concluded that inoculating lucerne crops can improve the fermentation quality as well as the nutritive value and lower proteolysis, and this effect is more pronounced at a high DM level. Also, Lalsil was more effective in improving the fermentation quality and in situ DM 
disappearance than Ecosyl was in wilted silages, which merits further research on aerobic stability and a response on animal performance. Although adding molasses to wilted lucerne crops improved in vitro OM digestion, stimulated heterofermentation rather than homofermentation at both added levels, it increased unavailable $\mathrm{N}$ concentrations only at the addition of $50 \mathrm{~g}$ molasses $/ \mathrm{kg}$.

\section{Acknowledgments}

The authors are grateful to the Isfahan University of Technology (Isfahan, Iran) for a grant and financial support of Farzad Hashemzadeh-Cigari's MSc. thesis research. The authors also thank Akbar Nikkhah (Zanjan University, Zanjan, Iran) for his helpful review of the manuscript.

\section{References}

AOAC, 2000. Official Methods of Analysis (1 $7^{\text {th }}$ ed.). Association of Official Analytical Chemists, Inc., Arlington, Virginia, USA.

Beever, D.E., 1993. Rumen function. In: Quantitative Aspects of Ruminant Digestion and Metabolism. ( $1^{\text {st }}$ ed.). Eds Forbes, J.M. \& France, J., CABI Publishing, Wallingford, UK. pp. 187-215.

Buxton, R., Muck, R.E. \& Harrison, F., 2003. Silage Science and Technology. American Society of Agronomy, Crop Science Society of America, Soil Science Society of America, Madison, WI, USA.

Charmley, E., Winter, K.A., McRae, K.B. \& Fillmore, S.A.E., 1996. Effect of inoculation on silage quality and performance of steers fed grass and cereal silages either alone or in combination. Can. J. Anim. Sci. 76, 571-577.

Donmez, N., Karsli, M.A., Cinar, A., Aksu, T. \& Baytok, E., 2003. The effects of different silage additives on rumen protozoa number and volatile fatty acid concentration in sheep fed corn silage. Small Rumin. Res. 48, 227-231.

Dubois, M., Giles, K.A., Hamilton, J.K., Rebes, P.A. \& Smith, F., 1956. Colorimetric method for determination of sugars and related substances. Anal. Chem. 28, 350-356.

Fedorak, P.M. \& Hurdy, D.E., 1983. A simple apparatus for measuring gas production by methanogenic cultures in serum bottles. Environ. Technol. 4, 425-432.

Filya, I., 2003. The effect of Lactobacillus buchneri and Lactobacillus plantarum on the fermentation, aerobic stability, and ruminal degradability of low dry matter corn and sorghum silages. J. Dairy Sci. 86, 3575-3581.

Filya, I., Muck, R.E. \& Contreras-Govea, F.E., 2007. Inoculant effect on lucerne silage: Fermentation products and nutritive value. J. Dairy Sci. 90, 5108-5114.

Giesecke, D. \& Stangassinger, M., 1980. Lactic acid metabolism. In: Digestive Physiology and Metabolism in Ruminants. Eds Ruckebush, Y. \& Thivend, P., AVI Publishing, Westport, CT. pp. 213-239.

Gordon, F.J., Dawson, L.E.R., Ferris, C.P., Steen, R.W.J. \& Kilpatrick, D.J., 1999. The influence of wilting and forage additive type on the energy utilisation of grass silage by growing cattle. Anim. Feed Sci. Technol. 79, 15-27.

Gül, M., Yorük, M.A., Karaoglu, M. \& Macit, M., 2008. Influence of microbial inoculation and molasses and their combination on fermentation characteristics and ruminal degradability of grass silages. Atatürk Üniv. Ziraat Fak. Derg. 39, 201-207.

Hetta, M., Cone, J.W., Bernes, G., Gustavsson, A.M. \& Martinsson, K., 2007. Voluntary intake of silages in dairy cows depending on chemical composition and in vitro gas production characteristics. Livest. Prod. Sci. 106, 47-56.

Hristov, V. \& McAllister, T.A., 2002. Effect of inoculants on whole-crop barley silage fermentation and dry matter disappearance in situ. J. Anim. Sci. 80, 510-516.

Ishler, V.A., Heinrichs, A.J., Buckmaster, D.R., Dams, S.A. \& Graves, R.E., 1992. Harvesting and utilizing silage. Penn State Cooperative Extension Circular 396.

Jimeno, I., Lazaro, M.J. \& Sollberger, H., 1995. Antagonistic interactions between propionic acid bacteria and non-starter lactic acid bacteria. Lait. 75, 401-413.

Jones, B.A., Satter, L.D. \& Muck, R.E., 1992. Influence of bacterial inoculant and substrate addition to lucerne ensiled at different dry matter contents. Grass Forage Sci. 47, 19-27. 
Jonsson, A., 1991. Growth of clostridium tyrobutiricum during fermentation and aerobic deterioration of grass silage. J. Sci. Food Agric. 54, 557-568.

Khorvash, M., Colombatto, D., Beauchemin, K.A., Ghorbani, G.R., \& Samei, A., 2005. Use of absorbants and inoculants to enhance the quality of corn silage. Can. J. Anim. Sci. 97-107.

Kowsar, R., Ghorbani, G.R., Alikhani, M., Khorvash, M. \& Nikkhah, A., 2008. Corn silage partially replacing short lucerne hay to optimize forage use in total mixed rations for lactating cows. J. Dairy Sci. 91, 4755-4764.

Kozelov, L.K., Iliev, F., Hristov, A.N., Zaman, S. \& McAllister, T.A., 2008. Effect of fibrolytic enzymes and an inoculant on in vitro degradability and gas production of low-dry matter lucerne silage. J. Sci. Food Agric. 88, 2568-2575.

Luchini, N.D., Broderick, G.A., Muck, R.E., Makoni, N.F. \& Vetter, R.L., 1997. Effect of storage system and dry matter content on the composition of lucerne silage. J. Dairy Sci. 80, 1827-1832.

McDonald, P., Henderson, A.R. \& Heren, S.J.E., 1991. The Biochemistry of Silage. $2^{\text {nd }}$ ed., Chalcombe Publ. Abersyth, U.K.

McDougall, E.I., 1948. Studies on ruminant saliva. I. The composition and output of sheep's saliva. Biochem. J. 43, 99-109.

Menke, K.H., Raab, L.L., Salewski, A., Steingass, H., Fritz, D. \& Schneider, W., 1979. The estimation of digestibility and metabolizable energy content of ruminant feedingstuffs from the gas production when incubated with rumen liqueur in vitro. J. Agric. Sci. 93, 217-220.

Muck, R.E. \& Pitt, R.E., 1993. Ensiling and its effect on crop quality. In: Silage: Field to Feedbunk. Proc. Nat. Silage Prod. Conf. Northeast Region, Agric. Engin. Serv., Ithaca, N.Y., USA. pp. 57-66.

Muck, R.E., Filya, I. \& Contreras-Govea, F.E., 2007. Inoculant effect on lucerne silage: In vitro gas and volatile fatty acid production. J. Dairy Sci. 90, 5115-5125.

Nadeau, E.M.G., Buxton, D.R., Russell, J.R., Allison, M.J. \& Young, J.W., 2000. Enzyme, bacterial inoculant, and formic acid effect on silage composition of orchardgrass and lucerne. J. Dairy Sci. $83,1487-1502$.

NRC, 2001. Nutrient Requirements of Beef Cattle ( $7^{\text {th }}$ ed.). National Academy Press, Washington D.C., USA.

Rizk, C., Mustafa, A.F. \& Phillip, L.E., 2005. Effects of inoculation of high dry matter lucerne silage on ensiling characteristics, ruminal nutrient degradability and dairy cow performance. J. Sci. Food Agric. 85, 743-750.

SAS, 2003. Statistical Analysis System version 9.1, SAS Institute Inc., Cary, N.C., USA.

Sheperd, A.C., Maslanka, M., Quinn, D. \& Kung, L., 1995. Additives containing bacteria and enzymes for lucerne silage. J. Dairy Sci. 78, 565-572.

Sniffen, C.J., O'Connor, J.D., Van Soest, P.J., Fox, D.G. \& Russell, J.B., 1992. A net carbohydrate and protein system for evaluating cattle diets: II. Carbohydrate and protein availability. J. Anim. Sci. $70,3562-3577$.

Soltani, A., Ghorbani, G.R., Alikhani, M., Samie, A.H. \& Nikkhah, A., 2009. Ground versus steamrolled barley grain for lactating cows: A clarification into conventional beliefs. J. Dairy Sci. 92, 3299-3305.

Umana, R., Staples, C.R., Bates, D.B., Wilcox, C.J. \& Mahanna, W.C., 1991. Effects of a microbial inoculant and or sugarcane molasses on the fermentation aerobic stability and digestibility of Bermudagrass ensiled at two moisture contents. J. Anim. Sci. 69, 4588-4601.

Van Soest, P.J., Robertson, J.B. \& Lewis, B.A., 1991. Methods of dietary fiber, neutral detergent fiber, and non-starch polysaccharides in relation to animal nutrition. J. Dairy Sci. 74, 3583-3597.

Vanzant, E.S., Cochran, R.C. \& Titgemeyer, E.C., 1998. Standardization of in situ techniques for ruminant feedstuff evaluation. J. Anim. Sci. 76, 2717-2729.

Weinberg, Z.G., Shbell, G.A. \& Hen, Y., 1999. The effect of Lactobacillus buchneri and L. plantarum, applied at ensiling, on the ensiling fermentation and aerobic stability of wheat and sorghum silages. J. Indust. Microbiol. Biotechnol. 23, 218-222.

Whiter, A.G. \& Kung, L., 2001. The effect of a dry or liquid application of Lactobacillus plantarum MTD1 on the fermentation of lucerne silage. J. Dairy Sci. 84, 2195-2202.

Zhang, J.G., Cai, Y., Kobayashi, R. \& Kumai, S., 2000. Characteristics of lactic acid bacteria isolated from forage crops and their effects on silage fermentation. J. Sci. Food Agric. 80, 1455-1460. 